\title{
ZLATA TKACH'S CONCERTO FOR PIANO AND ORCHESTRA AS A CULMINATION OF THE COMPOSER SYMPHONIC THINKING
}

\author{
Alyona Vardanyan \\ PhD in Art and Cultural Studies, Associate Professor, Acting Professor; \\ ORCID: 0000-0001-6469-4011; e-mail: aliona_piano@list.ru \\ Academy of Music, Theatre and Fine Arts of the Republic of Moldova, Chisinau, the Republic of Moldova
}

\begin{abstract}
The purpose of the article is to characterize Zlata Tkach's Piano Concerto as the culminating composition in the genre of the composer's symphonic music. The research methodology is based on the method of complex musicological analysis, due to which, the role of this work in the system of memorial genres of the author is determined, typical style features of her work late period are revealed, the thematic structure of the Concerto is characterized from the position of the manifestation of the principle of dialogicity and monothematism. The scientific novelty of the research is that for the first time, intonation processes in a Piano Concerto by Z. Tkach are systematically analyzed and the correlation of its traditional and innovative features is characterized. Being by genre attribution an opus with a pronounced desire to use modern means of expression, the concert is distinguished by the manifestation of the principle of microthematism and textural thematism. In the dramaturgical solution, the author conducts a constructive search in dynamic, timbre and rhythmic comparisons. At the same time, the intonational unity between the sections of the form, being the development of the romantic principle of poetry, is expressed in the form of monothematism. Conclusions. The creative method of $Z$. Tkach manifests itself in the synthesis of tradition and experiment. This is confirmed by the intonation-thematic structure of the Piano Concerto, in which the convergence of contrasting material contributes to the formation of an integral musical and dramatic concept. The motifs that form the basis of the monothematism complex establish intonation arches between the sections of a one-part composition, fastening them and subordinating them to a common plan. Important importance belongs to the opposition of the roles of the participants in the performance. Their dialogical activity is manifested in a peculiar way by the composer, primarily in the dialogue between the soloist and the orchestra: the interweaving of two contrasting figurative spheres is realized primarily in terms of content. The principle of monothematism is manifested especially vividly in the characterization of tragic reflections, painful reflections on the eternal conflict of the creative personality with the surrounding world, leading to a deep understanding of what exists. The other embodies the dynamism of life, dominating in the culmination of 'action', the accumulation of energy. Both the piano and the orchestra are equally involved in the development of both figurative principles. The resulting translational, purposeful movement towards the finale determines, along with the principle of monothematism, the integrity of the entire composition.
\end{abstract}

Keywords: Zlata Tkach; Piano Concerto; memorial theme; monothematism; microthematism; texture 


\section{Introduction}

One of the brightest events in the history of the Concerto for piano genre's development in Moldova during the last decade became the appearance of Concerto for piano and symphonic orchestra written by Zlata Tkach (1928-2006). It was dictated by a lot of reasons and, first of all, not only by the author's creative need but also by appearing a successful performing situation. The Concerto has found its listener and it was warmly accepted by the public at once (Ceaicovschi-Mereșanu, 1992).

Concerto for piano and symphonic orchestra written by Zlata Tkach is one of the most significant works of art of the last years of her life. First, it was presented in 2002 within the annual festival of modern music named 'Zilele muzicii noi' ('the Festival of New Music') in the performance of a young pianist Alexander Timofeev accompanied by symphonic orchestra of Philharmonic Society named after Serghei Lunkevich and conducted by $\mathrm{V}$. Doni. It has also been included in the program of a philharmonic concert commemorating the $100^{\text {th }}$ anniversary of the Jewish pogrom in Chisinau which took place in April 2003. Its performance by pianist Rimonda Sheinfeld proved and confirmed all the depth and potential richness of the figurative palette of the Concerto (Mironenco, 2009).

The composer started her work on it in 2001 and finished it in 2002. It was not her first appeal to the genre of Concerto in the field of which she has already created her works of art which make up the top of her instrumental creativity. The first among them became Concerto for violin, string and kettle drums which had been written in 1971. The traditions of the national violin performing school - both academic and those which came from Moldavian folklore professionalism and the art of travelling musicians - served as a basis for its creation. The Work was written after a tragic event in Zlata Tkach's life - the loss of her mother, and depth of sorrow and dramatic excitement was embodied in the character of the music with particular power.

In 1989 Zlata Moiseevna appeals to a certain genre once again having written 'Concerto for two performers on flutes'. Such an unusual title is connected with the fact that the author uses three different kinds of musical instruments in all the three parts of the Concerto - greater, small and viola flutes accordingly. This work of art occupies a particular place in the legacy of composers of Moldova representing the first experience of such a sort. Being unique in its conception the Concerto commemorated her father who died tragically not long before, undoubtedly, in its memorial character has a lot in common with Violin Concerto. The theme of death, of solemn thoughts and of complicated emotional and mental conditions, has been developing within the Concerto, further being realized in the musical atmosphere of Moldavian solemn songs, Jewish songs and dances.

Concerto for violin and piano which was intended by the author for pupils of the children's musical schools is a work of the composer, too. The author aims at performing opportunities of young violinists, having an aspiration to satisfy the practical need of increasing pedagogical repertoire due to the modern from the point of view musical language and also compositions of a large form performed on local musical material. Being supposed for educational purposes this work of art is also widely used in educational practice nowadays. The work has many art advantages and it also draws listeners' attention due to its bright figurativeness, well-remembered thematism, the integrity of idea that made this work of art to be accepted by teachers-violinists of Moldova. 
This Concerto together with other numerous works for different musical instruments is a definite row of works of methodical character in the composer's creative work.

The development of the theme 'În Memoriam' ('In Commemoration') outlined in her works a long time before and which is extremely important for Zlata Tkach is continued in Piano Concerto. This work of art is commemorated to victims of the Jewish pogrom which took place in Chisinau in April 1903. Realizing the main idea of the work and keeping her husband's advice - a famous musical critic E. M. Tkach - Zlata Moiseevna has included the theme of a song about pogrom from the repertoire of the well-known Jewish singer Isidor Belarskii into the Coda of her Concerto. The reference to a certain genre has been initiated by one of her pupils, namely Alexander Timofeev, who nowadays is a wellknown young performer. But then he was a graduate of the Republican musical lyceum named after Ch. Porumbesku where he had been studying in Zlata Tkach's class of composition. The author of these lines also taught him a special piano. Not only the process of learning and preparing the work of art for presenting at 'The Festival of New Music', but also maturing of his final idea passed before our eyes. First, it was realized as a variant for two grand piano performers. It was a very rare opportunity for observation and active participation in editing musical text. It was as if we were present at the creative laboratory of the author. Indeed, a serious pianist and mental potential of a young soloist should be taken into the composer's consideration, who aspired to provide stability of performing and certitude in realizing what had been planned.

Analysis of the latest research and publications. Information about the concerts of Moldovan composers can be found in the publications of E. Abramova, A. Miroshnikov, G. Kocharova (2000) and E. Mironenco (2009). Piano Concerto by Z. Tkach is analyzed for the first time by the author of this article and is reflected in a monograph devoted to the genre of piano concerto in the works of composers of the Republic of Moldova of the second half of the 20th - early 21 st centuries. (Vardanyan, 2017). The relevance of the article is determined by the importance of Z. Tkach's creative heritage., as well as the desire of young pianists to promote the Moldovan concert repertoire. Scientific novelty. For the first time, intonation processes are systematically analyzed in a Piano Concerto by $Z$. Tkach, characterized by the specifics of the creative idea.

\section{Purpose of the article}

The purpose of the article is to characterize Zlata Tkach's Piano Concerto as the culminating composition in the genre of the composer's symphonic music. Using the method of complex musicological analysis, the role of this work in the system of memorial genres of the author is determined, typical features of the style of the late period of her work are revealed, the thematic structure of the Concerto is characterized from the position of the manifestation of the principle of dialogicity and monothematism.

\section{Main research material}

From the point of view of compositional peculiarities, Piano Concerto is interesting because the most typical features of the composer's style of later period where common features with earlier created musical works are reflected in the character of 
themes, in methods of elaboration of material, in principles of organization of a form and construction of the texture. It was also promoted by a definite degree of complexity of expressive means selected by her. On a background of previous concerts where folklore tendencies were brightly displayed, and dancing elements adjoined to the song-recitative monologue forms of intonation, the role of generalized forms of melodic movement which are widely spread in modern music has come to light in a certain work. In this sense, Piano Concerto marks a certain shift to more 'abstract' thematism, despite the tendency to poetry exhibited in the common decision of its form. The use of a principle of monothematism, realized by the author in a new original interpretation proves the influence of poetry on it.

First of all, the one-part structure of the work comes from romantic poems, which was especially emphasized by the author in the subtitle 'Concert monopartit'. Its choice was realized in the so-called 'monocyclic' (R. Berberov's definition) structure where, however, all the necessary elements of a cycle are present. From the point of view of dramatic art in the Concerto, the composer shows the process of formation of the work as a complete and alive organism from its very beginning. The initial idea is already incorporated within the first bars and primary dialogue between the orchestra and a soloist. The author conducts the constructive search in the field of micro-thematic, texture thematic and also in the dramatic art of dynamic, timbre and rhythmic comparisons.

The composition of the Concerto is treated by the author very creatively. As a whole, the following structure which covers a great number of sections is drawn up:

A - the main part (Moderato non troppo)

$A_{1}-$ a linking part on the pattern of the main one $-f .2$

$\mathrm{B}$ - the secondary part (Andantino Dolce) - f.5

$\mathrm{C}$ - a final part (Meno Mosso, to a secondary part) - f. 11

$\mathrm{R}$ - the development (Allegro) - f. 13

$\mathrm{N}$ - an episode in the development on the pattern of a secondary part (Poco meno mosso) - f. 15

$\mathrm{A}_{2}$ - the first reprise, the main part (Tempo I) - f. 16

$\mathrm{B}_{1}$ - a secondary part (Meno Mosso) - f. 17

$\mathrm{A}_{3}-$ a linking part on the pattern of the main one $-\mathrm{f} .18,19$

$\mathrm{R}_{1}$ - the second development (Allegro) - f. 21

$\mathrm{N}_{1}$ - an episode in development № 2 (Meno Mosso) - f. 23

$\mathrm{C}_{1}$ - a final part - f. 24

$\mathrm{A}_{4}$ - the second, compressed reprise (the main part of the orchestra) - f. 25

$B_{2}$-a symbol of a secondary part of a grand piano - f. 25

$\mathrm{C}_{2}$ - the final part as a link with cadence - f. 27

Cadence (Cadenza) - 2 bars to f. 29

$A_{5}$ - preparation of Cadence on the pattern of the main part - f. 29

Code (Coda) - a theme of the Holocaust - f. 30

It is possible to see a precise composite-thematic scheme in their sequence: $A A_{1}$ B C R N A $\mathrm{B}_{1} \mathrm{~A}_{3} \mathrm{R}_{1} \mathrm{~N}_{1} \mathrm{C}_{1} \mathrm{~A}_{4} \mathrm{~B}_{2} \mathrm{C}_{2}$ Cadence $\mathrm{A}_{5}$ of the Coda.

The originality and singularity of the author's conception consist in an unexpected, innovative projection of the plan of Sonata Allegro, which demonstrates the free treat- 
ment of a romantic poem. Thus, unordinary - namely - double sonata form appears. The traditional consistent development of all the themes points out the presence of obligatory attributes of Sonata Allegro: A - the main part (f. 1), B - a secondary part (f. 5), $\mathrm{C}-$ a final part (f. 11). The presence of two developments which begin similarly but continue differently (f. 13 and f. 21) and two variously solved reprises (f. 16 and f. 23) point to a double sonata form. The Coda synthesizes all the thematic material and at the same time, it plays the role of the third development. Despite a big number of themes and sections included by the author in the Concerto, there are also strong uniting factors in it. So, the features of rondo forms of the second plan are present in the work where numerous realizations of a theme of the main part $(f .1,2,16,18,25$, 29) serve as a refrain. The themes of the other sections of the second plan indicate the beginning of each episode of this 'rondo'. Not only one refrain can be seen in this macro form, but also the developed multilevel system of refrains, in general, is found there, which is also proved by the triple $d_{e}$ velopment of the secondary $(f .5,17,25)$ and final (f. 11, 24, 27) parts.

As it was already mentioned, the principle of monothematism treated originally enough promotes thorough development within the whole composition. Here we shall remind, that the term 'monothematism' originates from the Greek word $\mu$ ovos which means 'one' or 'single', and ל $\boldsymbol{\varepsilon} \mu a$ - meaning something that is taken as a basis, and a method of taking out various musical themes from the main intonation kernel allows to achieve special unity of thematism and the integrity of a form, putting forward a specific of one theme or a set of themes. As it is known, the principle of monothematism serves as a powerful factor in uniting both sonata-symphonic cycles and large one-part forms.

Unlike the composers-romantics who relied on the idea of transformation and development of individualized initial thesis, Zlata Tkach in her Piano Concerto puts on the first place an intonation of neutral character, to be more exact - a constructive interval or a complex of simple intervals, what corresponds more to musical-technological principles of the 20th century. The means of micro-thematism, texture thematism and dramatic art of dynamic, timbre and rhythmic comparisons serves as a base for the composer. In this sense the initial intonation material rendered just within the first steps of orchestral prelude serve as a source for the whole main thematism. On its base, Zlata Tkach creates other themes of the composition by making essential some elements with their further transformation and expansion.

Following her usual manner, she scrupulously brings them out from the initial thesis impulse, being based on exhaustive interpretation of motivating-interval constructive cells what allows to achieve special capacity and laconism. Such an assertion of the initial complex as some kind of 'emblems', 'prompts' to the whole composition and at the same time an original 'genetic fund' is characteristic enough for Zlata Tkach and it is also presented in her great works of art (it is enough to remember the ballet 'Andriesh'). However, unlike the ballet where the concrete--genre folklore basis dominates, in Piano Concerto more 'abstract', 'sharp' and intense intonations of a minor second and a minor nona play the leading role. They are complemented by the courses on a minor third and a diminished quart which are often present in the Jewish music of the composer. In their coupling, an attentive view helps to find out ideas - symbols ciphered by Zlata Tkach. 
So, just in the initial two-bar structure of a primary theme, the similarity with palindromes variant of the monogram of D. Shostakovich D-Es-C-H is found out. The composer also reproduces other intonation formulas which have become symbols of the whole epochs. Presented in a ciphered way they get new sounding in a context of the whole Concerto. Among them intonation of the following fragment of a primary theme becomes important, reminding, on the one hand, about a leitmotif of destiny from R. Wagner's Rings of Nibelungen, and, on the other hand, which keeps the contours of monogram B-A-C-H, which, however, arises here at a new high level. Then it appears in the Coda at its primary, absolute height, in general; being built into the process of the general thematic development.

The use of a great variety of themes points to the domination of a variational-alternative principle of formation and development of thematism what gives intonation colourfulness and concentration to the author's statement despite its laconism.

Relying on a simple interval in the intonation pattern of the work has caused the prevalence of microthematism. In the principal section of the form - in the Prelude and then after exhibiting the initial thesis, two main motive components are distinguished courses to a minor second and a minor third. The GFS ('general forms of sounding', according to E. Ruchevskaya) prevail in their development, on whose background an intonation-relief theme of the Coda (f. 30, Allegro) which is the major dramaturgic accent of the whole Concerto sounds especially convincingly in further.

The Coda's function which traditionally serves as a logical result of the development of the main figurative spheres is seen more multiplane. Further drama forcing and reconsideration of the main part takes place here, as also the treatment of other themes is enriched: the secondary part gets a lyric-dramatic nuance but the choral of a final part maintains a clarified, quiet and concentrated image. However, I. Belarskii's theme treated as a theme of the Holocaust (f. 30) becomes a central part and culmination of the Coda. It introduces additional thematic contrast to a figurative-intonation sphere and simultaneously marks the beginning of a new stage in the development of a general musical-dramaturgic plan of the composition.

Its appearing in an epicentre of a drama semantic tensity of the whole work of art is connected, first of all, with hidden programming of the Concerto. Sounding as a restrained choral, it simultaneously introduces elements of contrast into the thematic system of the composition and assembles again its basic intonation complex. This theme seems to concentrate all the spirit of tragedy, sorrow and shock from terrible events which took place a century ago.

The symbolism of the moment is strengthened by mournfully sounding bells on a background of percussion instruments. Creating the effect of an echo on pianissimo, morendo, they seem to remind about the tragedy which happened long ago. In this aspect, the major value gets also the fact that the national colour of the theme of the Coda, namely that citation from I. Belarskii's song is concealed in the Concerto and seems as it is dissolved and comes on a foreground only during the most important, central dramaturgic moments. Thus, it is quite evident that the use of the citation even if it is obvious was not for the author only in an external manner but also promoted the enrichment of the whole composition. It testifies to the original understanding, sense of musical style and, first of all, its own individual style. As a result, given citation is not 
only conformable to thematism of the Concerto but also assembled all those intonations that served as a starting point for its formation. For this reason, it is not perceived as 'strange music'. As a result, the composer treats the method of introducing the 'strange word' by the absence of a clear boundary between 'strange' and 'our', which especially sharply emphasizes Zlata Tkach's intentions concerning her choice of expressive means and a character of intonation stylistics of the composition.

\section{Conclusions}

An antagonism and opposition of roles of the participants of the performance have great importance in Zlata Tkach's Piano Concerto. Their dialogical activity in its own way refracts from the composer. And, first of all, the dialogue between the soloist and orchestra is realized in substantial plan and also in the interlacing of two contrast figurative spheres.

One of them is represented by tragic thoughts, painful hesitations about the constant conflict of a creative person with the surrounding world, which leads to a deep understanding of reality. The other embodies the dynamism of life, dominating in the culmination of 'action' and the accumulation of energy. They both interact actively beginning with the Prelude and up to a final part of the art work. Their individual character is defined by the character of thematism which contains bright figurative contrasts. Whether the first sphere represents relief thematism with its aggravated and in many respects typical for the composer intonations, the second is based more likely on the general background forms of movement such as various sorts of passages, figurative constructions shaded by the introduction of colourfully sound-recording moments. Both a piano and orchestra participate equally in the development of both figurative beginnings. The progress which arises at the end and purposefulness of movement to the end causes the integrity of the whole composition, alongside a principle of monothematism. The author's orientation to a dialogue with the listener and openness and communicative art is quite conscious and all this makes up the essence of her creative activity.

In general, the originality of a plan and art advantages of Zlata Tkach's Piano Concerto allows to hope for its long life in pianist repertoire and also appearing of high-quality studio audio records in future.

\section{References}

Ceaicovschi-Mereșanu, G. (Comp.). (1992). Compozitori și Muzicologi din Moldova [The Composers and the Musicologists of Moldova]. Universitas [in Romanian].

Kocharova, G. (2000). Zlata Tkach: Sud'ba i Tvorchestvo [Zlata Tkach: Fate and Creativity]. Pontos [in Russian].

Mironenco, E. (2009). Concertul Instrumental în Creația Componistică din Moldova Instrumental [Concerto in the Composer's Creativity in the Republic of Moldova]. In Arta Muzicală din Republica Moldova: Istorie și Modernitate [The Musical Art of the Republic of Moldova: History and Modernity] (pp. 29-31). Grafema Libris [in Romanian].

Vardanyan, A. (2017). Fortepiannyi Kontsert v Tvorchestve Kompozitorov Respubliki Moldova: Vtoraya Polovina XX - Nachalo XXI vv. [The Concerto for Piano and Symphony Orchestra in 
the Creative Output of the Composers from the Republic of Moldova from the Second Half of the $20^{\text {th }}$ Century to Beginning of the $21^{\text {st }}$ Century]. LAMBERT Academic Publishing [in Russian].

\section{КОНЦЕРТ ДЛЯ ФОРТЕПІАНО З ОРКЕСТРОМ ЗЛАТИ ТКАЧ ЯК КУЛЬМІНАЦІЯ СИМФОНІЧНОГО МИСЛЕННЯ КОМПОЗИТОРА}

\section{Альона Варданян}

кандидат мистецтвознавства та культурології, доцент; ORCID: 0000-0001-6469-4011; e-mail: aliona_piano@list.ru

Академія музики, театру і образотворчих мистецтв Республіки Молдова, Кишинів, Республіка Молдова

\section{Анотація}

Мета дослідження - схарактеризувати концерт для фортепіано з оркестром 3. Ткач як кульмінаційний твір у сфері симфонічної музики композитора. Методологія дослідження. Використання комплексного музикознавчого аналізу дозволило визначити роль твору в системі меморіальних жанрів 3. Ткач, виявити типові риси стилю пізнього періоду їі творчості, визначити тематичну структуру концерту, що складається під впливом принципів діалогічності та монотематизму. Наукова новизна дослідження. Вперше системно проаналізовано інтонаційні процеси у фортепіанному концерті 3. Ткач, розглянуто співвідношення традиційних та новаторських особливостей. Бувши за стильовою приналежністю опусом із яскраво вираженим прагненням до використання сучасних виразних засобів, концерт демонструє прояв принципу мікротематизму та фактурного тематизму. У драматургічному рішенні автор впроваджує конструктивний пошук у галузі динамічних, тембрових та ритмічних зіставлень. Висновки. Творчий метод 3. Ткач проявляє себе у синтезі традиції та експерименту. Це підтверджується інтонаційнотематичною структурою фортепіанного концерту, в якому зближення контрастного матеріалу сприяє формуванню цілісної музично-драматичної концепції. Мотиви, що $€$ основою монотематичного комплексу, утворюють інтонаційні арки між розділами одночастинної композиції, скріплюючи їх і підпорядковуючи загальному плану. Важливе значення має протиставлення функцій учасників вистави. Їхня діалогічна активність своєрідно проявляється композитором, реалізуючись насамперед у змістовному плані у діалозі соліста та оркестру, у переплетенні двох контрастних образних сфер. Принцип монотематизму яскраво проявляється у характеристиці сфери трагічних монологів, хворобливих роздумів про вічний конфлікт творчої особистості з навколишнім світом, що веде до глибокого розуміння всього сущого. Інша образна сфера втілює динамізм життя, що домінує у кульмінації «дії», накопичення енергії. I фортепіано, і оркестр однаково беруть участь у розвитку обох образних принципів. Поступальний, цілеспрямований рух до фіналу визначає, поряд з принципом монотематизму, цілісність всієї композиції.

Ключові слова: Злата Ткач; концерт для фортепіано з оркестром; меморіальна тематика; монотематизм; мікротематизм; фактура 


\section{КОНЦЕРТ ДЛЯ ФОРТЕПИАНО С ОРКЕСТРОМ ЗЛАТЫ ТКАЧ КАК КУЛЬМИНАЦИЯ СИМФОНИЧЕСКОГО МЫШЛЕНИЯ КОМПОЗИТОРА}

\section{Алена Варданян}

кандидат искусствоведения и культурологии, доцент; ORCID: 0000-0001-6469-4011; e-mail: aliona_piano@list.ru

Академия музыки, театра и изобразительных искусств Республики Молдова, Кишинёв, Республика Молдова

\section{Аннотация}

Цель исследования - охарактеризовать концерт для фортепиано с оркестром 3. Ткач как кульминационное сочинение в области симфонической музыки композитора. Методология исследования. Использование комплексного музыковедческого анализа позволило определить роль данного произведения в системе мемориальных жанров 3. Ткач, выявить типичные черты стиля позднего периода ее творчества, определить тематическую структуру концерта, складывающуюся под влиянием принципов диалогичности и монотематизма. Научная новизна исследования. Впервые системно проанализированы интонационные процессы в фортепианном концерте 3.Ткач, рассмотрено соотношение традиционных и новаторских особенностей. Являясь по стилевой принадлежности опусом с ярко выраженным стремлением к использованию современных выразительных средств, концерт демонстрирует проявление принципа микротематизма и фактурного тематизма. В драматургическом решении автор внедряет конструктивный поиск в области динамических, тембровыхи ритмических сопоставлений. Выводы. Творческий метод 3. Ткач проявляет себя в синтезе традиции и эксперимента. Это подтверждается интонационно-тематической структурой фортепианного концерта, в котором сближение контрастного материала способствует формированию целостной музыкально-драматической концепции. Мотивы, составляющие основу монотематического комплекса, образуют интонационные арки между разделами одночастной композиции, скрепляя их и подчиняя общему плану. Важное значение имеет противопоставление функций участников спектакля. Их диалогическая активность своеобразно проявляется композитором, реализуясь прежде всего в содержательном плане - в диалоге солиста и оркестра, в переплетении двух контрастных образных сфер. Принцип монотематизма особенно ярко проявляется в характеристике сферы трагических монологов, болезненных размышлений о вечном конфликте творческой личности с окружающим миром, ведущем к глубокому постижению всего сущего. Другая образная сфера воплощает динамизм жизни, доминирующий в кульминации "действия», накопление энергии. И фортепиано, и оркестр в равной степени участвуют в развитии обоих образных принципов. Возникающее в результате поступательное, целенаправленное движение к финалу определяет, наряду с принципом монотематизма, целостность всей композиции.

Ключевые слова: Злата Ткач; концерт для фортепиано с оркестром; мемориальная тематика; монотематизм; микротематизм; фактура 